\title{
DIAGNOSIS PENYAKIT VIRAL PADA UDANG WINDU, Penaeus monodon SECARA HISTOPATOLOGIS DAN ANTIBODI POLIKLONAL DENGAN METODE ELISA
}

\author{
Mun Imah Madeali*), Arifuddin Tompo ${ }^{*}$ dan Muliani*)
}

\begin{abstract}
ABSTRAK
Udang yang dikoleksi dari beberapa lokasi tambak di Sulawesi Selatan digunakan untuk mengidentifikasi penyakit viral yang menyebabkan kegagalan panen pada bulan Juni-Agustus 1997. Diagnosis secara histopatologis dilakukan dengan fiksasi sampel dalam larutan Davidson's dan diproses secara rutin melalui dehidrasi bertingkat pada ethanol, kemudian diwarnai dengan pewarnaan Hematoxilin dan Eosin serta diamati di bawah mikroskop. Diagnosis secara ELISA menggunakan antibodi poliklonal yang diproduksi sendiri melalui penyuntikan pada mencit balb/c. Secara histopatologik, didapatkan tiga jenis virus yang menginfeksi udang di Sulawesi Selatan baik di panti benih maupun di tambak yaitu berurutan dari yang terbanyak Monodon Baculo Virus, White Spot Baculo Virus dan Hepatopancreatic Parvo-like Virus. Analisis protein virus dari masing-masing lokasi menunjukkan bahwa antigen virus dari Bulukumba mengandung protein paling tinggi yaitu $30,17 \mathrm{mg} / \mathrm{mL}$, menyusul antigen virus dari Maros $18,5 \mathrm{mg} / \mathrm{mL}$, Bone $13,72 \mathrm{mg} / \mathrm{mL}$ dan paling rendah adalah dari Pangkep $7,72 \mathrm{mg} / \mathrm{mL}$. Hasil estimasi protein tersebut sejalan dengan hasil pengujian secara ELISA menggunakan antibodi poliklonal yang positif bagi sampel dari semua lokasi. Udang yang berasal dari Bulukumba mendapat serangan virus paling tinggi, dikaji dari nilai optical density pada titer antibodi yang mencapai 1,81, dibandingkan nilai optical density udang sehat 0,12 .
\end{abstract}

ABSTRACT: Diagnosis of viral diseases in tiger shrimp, Penaeus monodon based on histopathological appearances and polyclonal antibody in ELISA. By: Mun Imah Madeali, Arifuddin Tompo and Muliani.

Tiger shrimps were collected from shrimp ponds in four regencies in South Sulawesi for diseases diagnostic between June-August 1997. The samples were fixed in Davidson's solution before processed in a routine dehydration using ethanol and stained with Hematoxylin and Eosin. For ELISA method, shrimp hepatopancreas were frozen before used for antigen and polyclonal antibody preparation using white mouse balb/c. Histopathologically, three viruses were detected ie. Monodon Baculo Virus, White Spot Baculo Virus, and Hepatopancreatic Parvo-like Virus. The results of protein estimation of original virus antigen matched those of the ELISA method using polyclonal antibody, and showed that the samples originated from Bulukumba has the highest concentration of protein. The value of optical density resulted by ELISA using polyclonal antibody for Bulukumba shrimp was 1.81, much higher compared to optical density value of health shrimp which was only 0.12 .

KEYWORDS: viral diseases, tiger shrimp, polyclonal antibody, histopathologic.

\section{PENDAHULUAN}

Penyakit viral merupakan masalah serius pada usaha budidaya udang windu di tambak karena dalam waktu yang relatif singkat dapat menyebabkan kematian massal. Menurut Chen \& Kou (1989), Baculo virus merupakan patogen penyebab kematian berbagai spesies udang seperti
Penaeus monodon Fabricius, P.duorarum Burkenroad, P.setiferus De Haan, P.vannamei Boone dan P.japonicus Bate.

Sejauh ini penelitian yang mengarah kepada aspek yang menyangkut keganasan virus (patogenesitas) atau virulensi pada berbagai jenis dan umur udang yang berbeda belum pernah dilakukan. Puslitbang Perikanan (1994) melaporkan

\footnotetext{
Peneliti pada Balai Penelitian Perikanan Pantai
} 
telah diketahui adanya infeksi penyakit oleh virus atau virus-like pada komoditas udang di Indonesia, baik pada udang yang kelihatannya sehat maupun yang sakit, terutama oleh White Spot Baculo Virus (WSBV) dan Monodon Baculo Virus (MBV) dengan pemeriksaan secara langsung (mikroskopis) dan histologis (Mangunwiryo, 1990). Dari 20 panti benih yang terdapat di Ilo-Ilo Philipina, secara histologis 18\% dari sampel yang diperoleh didapatkan adanya infeksi oleh MBV dan 45\% infeksi oleh HPV (Anonimous, 1996). Nadala et al. (1997) telah mengisolasi dan mengkarakterisasi dua jenis virus udang windu yang mempunyai sifat patogenik yang tinggi dengan menggunakan SDS-polyacrilamide gel electrophoresis (SDS-PAGE) yaitu Yellow Head Virus (YHV) dan Chinese Baculo Virus (CBV) yang juga dikenal dengan WSBV. Namun demikian identifikasi virus dan studi virulensi/ patogenesitas masih diperlukan dengan teknik lain yang modern seperti Enzyme Linked Immunosorbent Assay (ELISA) (Lewis, 1986; Burgess, 1995).

Diagnosis secara ELISA memerlukan antibodi (monoklonal, AbMo atau poliklonal, $\mathrm{AbPo}$ ) yang dapat diperoleh di pasaran (untuk virus tertentu) atau diproduksi sendiri melalui penyuntikan beberapa ekor hewan dan dipanen setelah beberapa kali suntikan, sehingga jumlahnya akan terbatas (Zola, 1993). Antibodi monoklonal atau poliklonal khusus untuk virus pada udang belum didapatkan di pasaran, sehingga dewasa ini penggunaan teknik ELISA untuk mengdiagnosis penyakit viral pada udang harus diproduksi sendiri. Parede (1997) mengatakan bahwa sampai saat ini cara yang mudah untuk menghasilkan $\mathrm{Ab}$ (Immunoglobin;-Ig) yaitu dengan menyuntikkan antigen. Antigen (Ag) merangsang aktivitas selsel limpoid berbagai organ (sumsum tulang, limpa, kelenjar limfe) untuk memproduksi Ig yang nantinya disekresikan ke dalam darah (serum). Untuk mendiagnosis penyakit secara spesifik memerlukan antibodi monoklonal di mana AbMo tersebut dapat secara langsung mengenal jenis virus yang terdapat dalam Ag yang diujikan. Beberapa perbedaan yang dapat diketahui antara $\mathrm{AbMo}$ dan AbPo ialah bahwaAbMo berasal dari satu sel sedangkan AbPo berasal lebih dari satu sel, sehingga AbMo mempunyai reaksi yang spesifik. AbMo dapat dibuat secara in vitro dan in vivo sedangkan $\mathrm{AbPo}$ hanya dapat. dibuat secara in vivo. Pembuatan AbMo memerlu- kan waktu yang relatif lama yaitu 6-12 bulan, sedangkan AbPo dapat diproduksi dalam jangka waktu kurang dari enam bulan. Adapun AbMo dapat digunakan untuk uji spesifik, imunocitokimia dan terapi, sedangkan AbPo digunakan untuk pengujian secara umum dan terapi.

Dalam laporan ini jenis antibodi yang digunakan adalah antibodi poliklonal di mana hasil pengujian untuk diagnosis penyakit belum spesifik terhadap satu jenis virus.

\section{BAHAN DAN METODE}

\section{Diagnosis Secara Histopatologis}

Dalam penelitian ini sampel yang diperoleh untuk pemeriksaan histopatologis berasal dari 100 ekor udang windu umur 50-70 hari masa pemeliharaan di tambak yang diambil dari lima lokasi di Sulawesi Selatan yaitu Bulukumba, Bone, Maros, Pangkep, dan Pinrang dan 100 ekor benih udang windu umur pasca larva 15 masing. masing dari tiga unit pembenihan udang yaitu di Takalar, Bone dan Barru.

Sampel dikoleksi pada bulan Juni-Agustus 1997. Dalam hal teknik pengambilan sampel, lokasi pengambilan sampel ditentukan berdasarkan adanya gejala serangan penyakit pada suatu lokasi dan udang windu yang dikoleksi adalah udang windu yang mempunyai gejala klinis terserang penyakit.

Jenis organ yang dikoleksi untuk pemeriksaan histopatologis berupa hepatopankreas, daging dekat lapisan epidermis pada bagian kulit untuk udang windu dari tambak, sedangkan untuk benih udang diambil secara utuh. Organ tersebut difiksasi dengan larutan Davidson's dan dibawa ke Laboratorium Patologi Fakultas Kedokteran Hewan Institut Pertanian Bogor untuk diproses secara rutin yang meliputi dehidrasi, embedding, pewarnaan Hematoksilin dan Eosin (H\&E) dan pemeriksaan histopatologis di bawah mikroskop.

Kriteria yang dipakai untuk mendiagnosis penyakit viral secara histopatologis berupa inclusion body pada sel organ yang dikoleksi. Dalam penelitian ini, pengamatan histopatologis dilakukan berdasarkan perubahan inclusion body yang merupakan ciri-ciri morpologis dari suatu jenis virus (Lightner, 1996). 


\section{Diagnosis Menggunakan AbPo dengan Metode ELISA}

\section{Waktu dan tempat}

Penelitian ini dilakukan di Laboratorium Patologi Balai Penelitian Perikanan Pantai, Maros dan Laboratoriun Virologi Balai Penelitian Veteriner Bogor. Penelitian berlangsung mulai bulan Juni sampai dengan Desember 1997.

\section{Antigen (Ag)}

Antigen yang digunakan dalam penelitian ini adalah yang berasal dari hepatopankreas udang windu umur 50-60 hari masa pemeliharaan di tambak yang memperlihatkan gejala serangan penyakit virus dengan tanda-tanda terdapat bintik putih pada bagian karapas seluruh tubuh sebagai indikasi adanya serangan WSBV atau terlihat adanya warna merah pada setiap segmen tubuh udang yang merupakan indikasi serangan MBV.

Adapun proses penyediaan Ag adalah sebagai berikut:

Hepatopankreas sampel udang yang dikoleksi dari lapangan disimpan dalam deep-freezer sebelum diproses lebih lanjut.

Hepatopankreas udang digerus dengan tissue grinder dalam air laut steril dengan pengenceran $10 \%$

- Disentrifus dengan kecepatan $3000 \mathrm{rpm}$ selama 15 menit.

Supernatan yang dihasilkan disentrifus kembali dengan kecepatan $6000 \mathrm{rpm}$ selama 15 menit.

Supernatan difilter dengan filter milipore 0,45 mikron dan hasilnya disebut Pasase 0 (Po).

Po yang dihasilkan diberi kode sesuai dengan asalnya yaitu PoMa, PoPk, PoBn dan PoBk.

Keempat Po yang telah dihasilkan tersebut kemudian diuji tular kepada udang sehat menurut metode Sano et al. (1985) dan Langdon (1989).

Udang windu yang ditulari dengan Po tersebut kemudian dipanen lagi hepatopankreasnya apabila telah menunjukkan gejala mulai terinfeksi dengan indikasi udang mulai stres.
Hepatopankreas diproses kembali seperti proses pembuatan Po dan hasilnya adalah P1Ma, P1Pk, P1Bn dan P1Bk.

Keempat P1 setelah dipekatkan dengan menggunakan Amicon filter disebut Antigen (Ag) yang siap disuntikkan ke tikus putih (mencit balb/c) untuk proses immunisasi.

\section{Immunisasi}

Mencit balb/c jantan dewasa (umur enam minggu) digunakan sebagai hewan uji. Penentuan konsentrasi sediaan Antigen (P1) yang disuntikkan secara intraperitonial (ip) berdasarkan estimasi protein dari antigen yang telah diproduksi yaitu antara 1,0-1,7 mL/ekor tikus pada periode pertama. Penyuntikan ulang (booster) dilakukan setiap 14 hari dengan jenis dan dosis antigen yang sama. Setiap sebelum booster, dilakukan pengambilan darah tikus pada daerah mata sebanyak 2 cc. Darah tikus yang diambil tersebut merupakan antibodi poliklonal yang selanjutnya digunakan untuk mendiagnosis penyakit viral secara ELISA.

\section{Penggunaan ELISA tak langsung pada skrining antibodi poliklonal}

Kelima antigen masing-masing dilarutkan di dalam bufer karbonat-bikarbonat $\mathrm{pH}$ 9,6 diletakkan pada lempeng ELISA mikro-titer dengan dasar lubang berbentuk U (U-shape bottom), kemudian dieramkan selama satu malam pada suhu $4^{0} \mathrm{C}$. Lempeng ELISA tersebut selanjutnya dicuci tiga kali dengan Phosphate Buffer Saline mengandung tween-20 0,05\% (v/v) (PBS-T). Sebanyak $50 \mu \mathrm{L}$ supernatan asal medium penumbuh hibridoma dimasukkan ke dalam masing-masing lubang lempeng ELISA tadi, yang kemudian dieramkan pada suhu kamar selama satu jam. Setelah itu pencucian dengan menggunakan PBS-T kembali dilakukan. Larutan konjugat anti $\lg \mathrm{G}$ mencit yang dirunut dengan ensim "Horse radish peroxidase" ((HRP) di dalam bufer tris-EDTA-salin-tween mengandung kasein $0,02 \%(w / v)$ (TEN-T-C) ditambahkan ke dalam masing-masing lubang lempeng ELISA yang selanjutnya kembali dieramkan pada suhu kamar selama satu jam. Lempeng ELISA tersebut kemudian dicuci seperti perlakuan serupa di atas. Sebanyak $100 \mu \mathrm{L}$ larutan substrat mengandung 1,04 M ABTS ditambahkan ke dalam masing- 
masing lubang lempeng ELISA dan dieramkan pada suhu kamar selama satu jam, kemudian perubahan warna dapat dibaca dengan "ELISAPlate Reader" Titertek Multiskan MK II (Flow Lab. Finland) pada panjang gelombang $414 \mathrm{~nm}$ setelah 60 menit. Pada setiap lempeng ELISA selalu disertakan kontrol positif, kontrol negatif dan kontrol konjugat.

\section{HASIL DAN PEMBAHASAN}

\section{Diagnosis Secara Histopatologis}

Berdasarkan diagnosis secara histopatologis, terjadi kelainan pada jaringan hepatopankreas yaitu inclusion body sebagai akibat kerja dari virus untuk setiap lokasi sampling. Inclusion body yang nampak pada jaringan yang diamati merupakan ciri-ciri morfologis dari virus yang didasarkan atas petunjuk dari Lightner (1996). Didapatkan tiga jenis virus yang menginfeksi udang di tambak dan di panti benih yaitu MBV, WSBV, dan HPV. Lokasi dan gejala yang ditimbulkan oleh ketiga jenis virus tersebut dapat dilihat pada Tabel 1.

Diagnosis penyakit viral pada benur udang windu didapatkan adanya infeksi virus dari benur yang berasal dari Barru dan Takalar, sedangkan benur dari panti benih yang ada di Bone bebas dari virus. Hasil diagnosis dari tiga ekor induk udang windu yang berasal dari Aceh didapatkan positif terinfeksi oleh MBV. Dari kenyataan tersebut, dapat dikemukakan bahwa penyakit viral yang menginfeksi udang di tambak dan menyebabkan kematian kemungkinan berasal dari induk yang secara vertikal diturunkan kepada anaknya (benur) dan pada kondisi lingkungan yang menurun secara horisontal menyebabkan penyakit tersebut berkembang dan menyebabkan kematian udang. Hasil penelitian Madeali dkk. (1997), diketahui bahwa mikroorganisme patogen, utamanya bakteri, dapat meningkatkan populasinya pada kondisi lingkungan yang buruk dengan kandungan BOT 30-50 ppm dan salinitas rendah (15-24 ppt). Diduga mikroorganisme golongan virus juga akan berkembang dalam kondisi kualitas air seperti yang terjadi pada bakteri. Hal ini dapat dilihat dari peman- tauan di lapangan, di mana udang yang terserang penyakit tersebut rata-rata setelah berumur 60 . 70 hari masa pemeliharaan dengan kualitas air yang mulai menurun.

Berdasarkan Tabel 1 di atas, terlihat bahwa jenis MBV ditemui pada setiap lokasi sampling, sedangkan HPV tidak selalu. White Spot Baculo Virus juga banyak didapatkan pada setiap lokasi. Namun demikian belum dapat diketahui dengan pasti satu jenis virus yang merupakan penyebab kematian udang windu di tambak karena masih diperlukan studi lebih lanjut tentang sifat dan keganasan setiap virus yang didapatkan. Selanjutnya dapat diketahui bahwa penyakit viral yang menyebabkan kematian udang windu telah menyebar ke hampir semua areal pertambakan di Sulawesi Selatan.

Penampakan secara morpologis dan inclusion body yang terjadi pada inti sel dalam jaringan udang yang terserang penyakit viral dapat dilihat pada Gambar 1 dan Gambar 2. Secara morpologis, gejala serangan penyakit viral yang disebabkan oleh MBV dapat dilihat adanya perubahan warna kulit menjadi merah pada setiap segmen (segmen merah) dan terdapat bercak putih pada bagian kulit udang yang terserang WSBV.

\section{Diagnosis secara ELISA dengan Antibodi Poliklonal}

Hasil uji ELISA terhadap titer Antibodi Poliklonal masing-masing mencit yang telah disuntik dengan $\mathrm{Ag}$ menunjukkan hasil positif dimana AbPo yang dihasilkan mengenal adanya benda asing yang terdapat pada Ag yang diujikan. Nilai OD optimum pada ELISA Reader yang terbaca setelah 60 menit pada pengenceran Ag 1:400 dari sampel serum positif (+) $\mathrm{Ag}$ asal Bulukumba $(\mathrm{P} 1 \mathrm{Bu}=1,81)$ mempunyai nilai tertinggi menyusul P1Ma $(1,70)$, P1Bn $(1,60)$, dan terendah $\mathrm{P} 1 \mathrm{Pk}(0,91)$. Nilai OD tersebut berkorelasi dengan hasil analisis protein di mana $\mathrm{Ag}$ asal Bulukumba mengandung protein virus paling tinggi yaitu $30,17 \mathrm{mg} / \mathrm{mL}$, menyusul $\mathrm{Ag}$ asal Maros $18,5 \mathrm{mg} / \mathrm{mL}, \mathrm{Ag}$ asal Bone $13,72 \mathrm{mg} / \mathrm{mL}$ dan terendah $\mathrm{Ag}$ asal Pangkep 7,72 $\mathrm{mg} / \mathrm{mL}$ (Gambar 3). Nilai OD dari masing-masing lokasi dapat dilihat pada Gambar 4. 
Tabel 1. Penyebaran dan gejala penyakit yang dischabkan oleh virus pada udang windu di tambak dan panti benih di Sulawesi Selatan.

Table 1. Distribution and clinical signs of viral diseases on liger shrimp in South Sulauesi.

\section{Lokasi (Location)}

Tambak (Grome-out ponds):

1. Bone

2. Bulukumba

3. Maros

1. Pangkel)

Panti benih udang

windu (Shrim)

hatchorits):

- Broodstork

- Post larvar

1. Bone

Monodon Baculo Virus

3. Takalat
Monodon Baculo Virus

White Spot Barculo Virus

Hepatopancreatic Parvo-like Virus Monodon Baculo Virus

Hepatopancreatic Parou-like Virus Monodon Barulo Virus

White Spot Baculo Virus

Hepatopenereatie Parvo-like Virus Monodon Barulo Virus

White Spot Barule Virtus

Monodon Baculo Virus

White Spot Baculo Virms

Monodon Baculo Virus

White Spot Baculo Virus

\section{Indikator serangan (Clinical signs)}

Berenang ke pinggir (Swim lethegically on the sides of the ponds)

- Segmen merah (Reddish abdomen)

Usus kosong (Empty intestine)

Berenang ke pinggir (Swim lothagically on the sides of the pends) Segmen merah (Reddish abdomen) Bintik putih (White spot)

Usus kosong (Empty intestine)

Berenang ke pinggir (Swim lothu. gically on the sides of the ponds)

- Segmen merah (Reddish abdomen) Bintik putih (White spot)

Usus kosong (Empty intestins)

- Berenang ke pinggir (Swim lethagically on the side's of the ponds)

- Segmen merah (Reddish abdomen)

- Bintik putih (White spot)

- Usus kosong (Empty inte'stine)
Tidak jelas (Unclear)

Tidak jelas (Unclorar) 


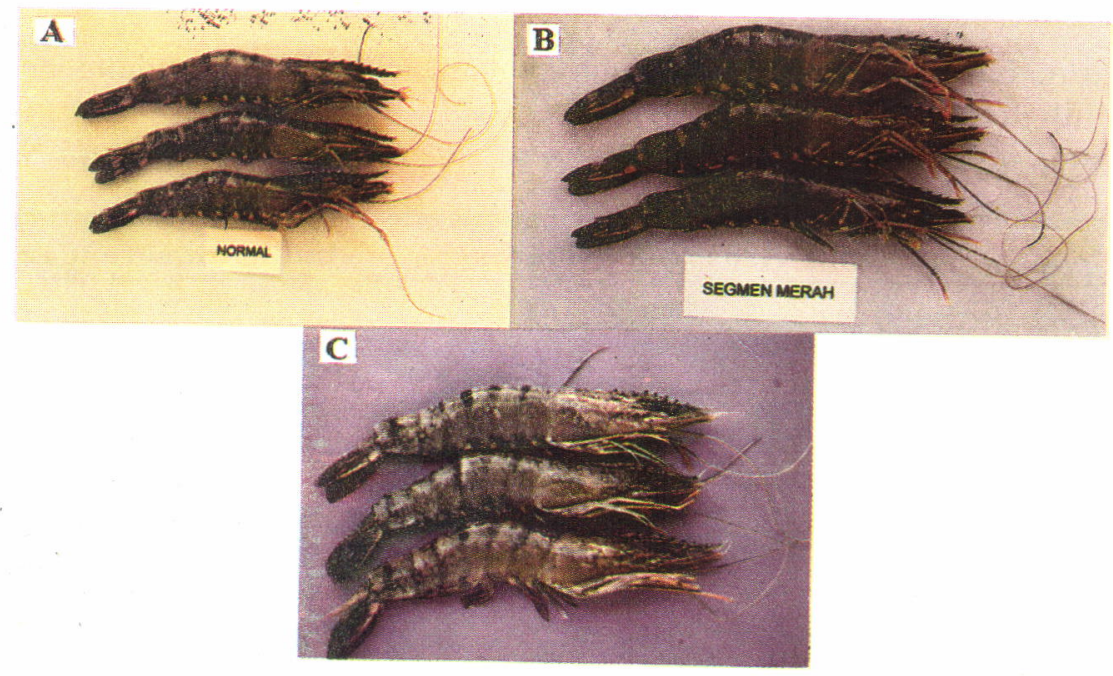

Gambar 1. Penampakan secara morphologis udang sehat ( $\mathrm{A}=$ warna hijau kehitaman), udang terserang MBV (B = warna merah pada abdomen) dan udang terserang WSBV $(\mathrm{C}=\operatorname{spot}$ putih pada karapas).

Fiqure 1. Morphological appearances of normal shrimp ( $A=$ greenish black color), MBV-infected shrimp $(B=$ reddish color $)$, and WSBV-infected shrimp $(C$ - white spot on the carapace)

A

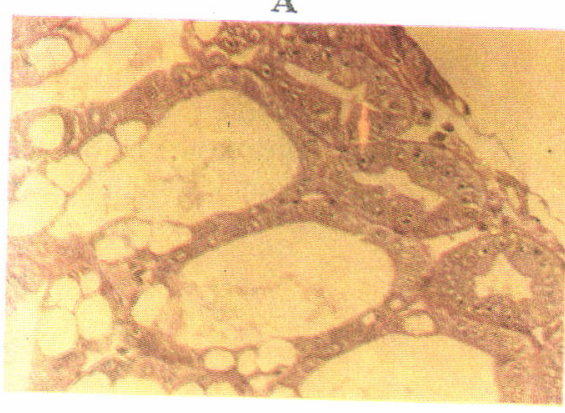

C

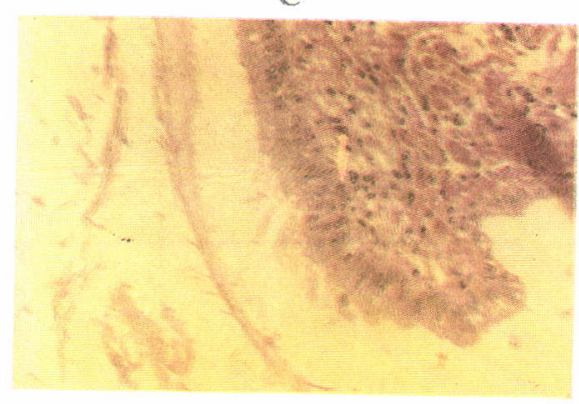

B

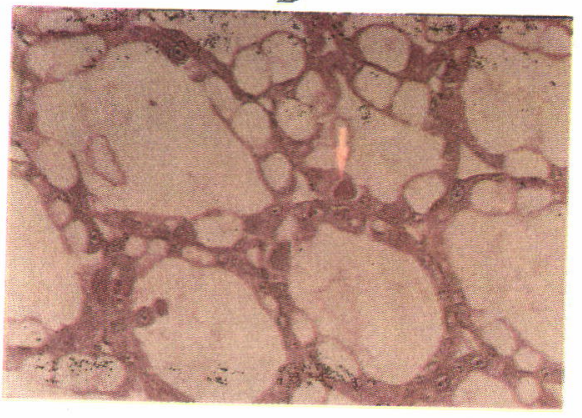

D

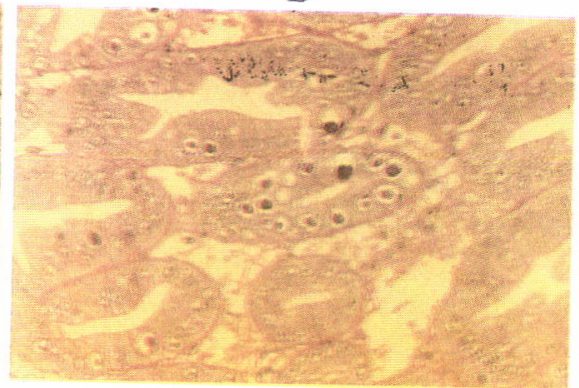

Gambar 2. Penampakan hepatopankreas udang normal (A = nukleus berada ditengah sel), udang terserang MBV ( $\mathrm{B}$ = inclusion body yang berwarna kemerahan), udang yang terserang WSBV (C = inclusion body yang berwarna merah jambu), dan udang terserang HPV (D) = inclusion body yang berwarna violet).

Figure 2. Appearances of hepatopancreas of normal shrimp ( $A=$ nucleus is found in the center of cells), MBV-infected shrimp ( $B$ = reddish color inclusion bodies), WSBV-infected shrimp (C $=$ pink and reddish color inclusion bodies), and HPV-infected shrimp $(D=$ compact violet color inclusion bodies). 


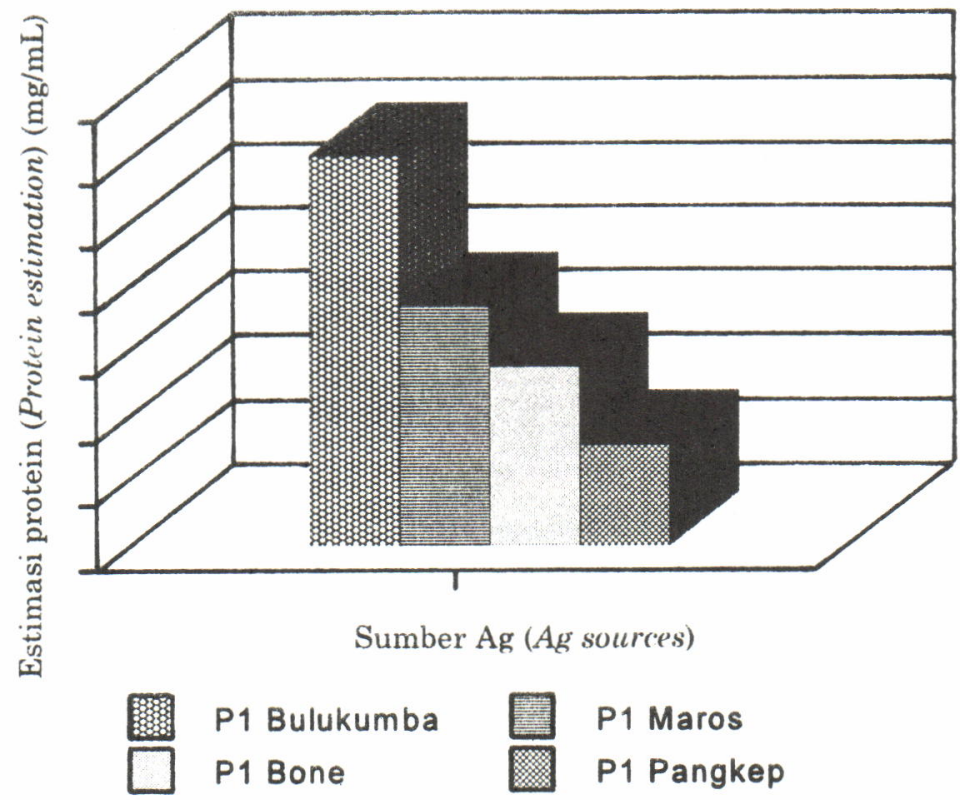

Gambar 3. Estimasi protein Ag virus udang dari sejumlah tambak udang di Sulawesi Selatan.

Figure 3. Protein estimation of virus antigen of tiger shrimp collected from several of brackishwater ponds in South Sulawesi.

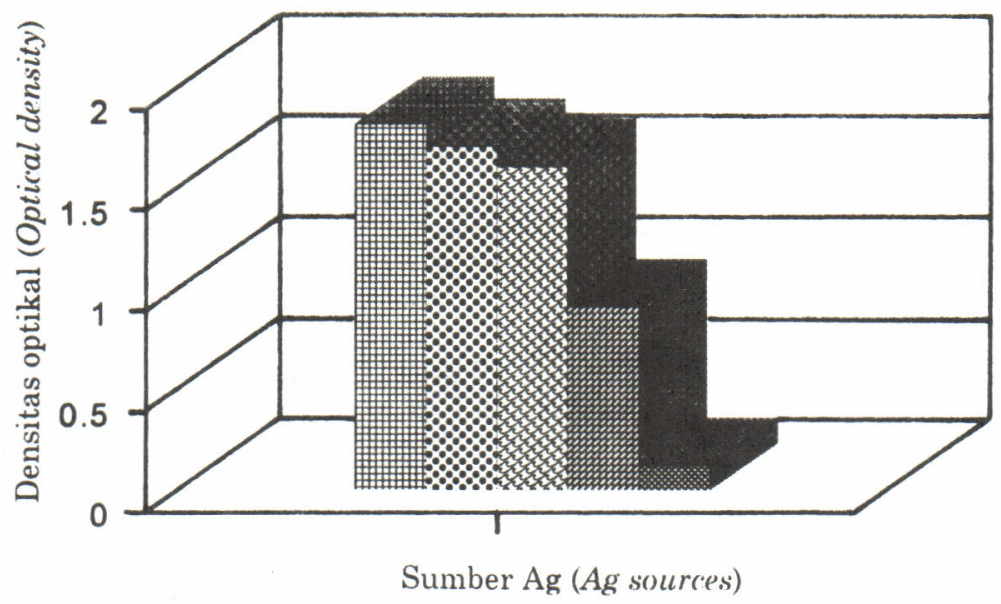

\begin{tabular}{|c|c|c|}
\hline P1 Bulukumba & 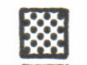 & P1 Maros \\
\hline P1 Bone & 皪幻 & P1 Pangkep \\
\hline
\end{tabular}

Gambar 4. Nilai optical density (OD) antigen masing-masing lokasi.

Figure 4. Optical density $(O D)$ values of different sources of antigen. 
Gambar 4 memperlihatkan bahwa udang sampel yang diambil dari masing-masing lokasi positif terserang oleh penyakit viral di mana sampel dari Bulukumba mendapat serangan paling tinggi. Sampel udang yang dianggap sehat pun (kontrol) terserang oleh virus walaupun serangannya belum tinggi dan belum sampai mematikan udang

\section{KESIMPULAN DAN SARAN}

Hasil diagnosis baik secara histopatologis maupun secara ELISA menunjukkan bahwa penyakit yang disebabkan oleh virus pada udang windu didapatkan pada semua lokasi sampling. Virus tersebut kemungkinan berasal dari induk udang yang secara vertikal diturunkan kepada anaknya dan berkembang secara horisontal dengan cepat pada saat budidaya di tambak dengan kondisi kualitas air yang kurang memadai.

Beberapa saran yang dapat diberikan dalam rangka usaha penanggulangan penyakit viral pada udang adalah antara lain: vaksinasi induk udang, memproduksi induk dan benur yang bebas penyakit (disease-free broodstock and fry) dan memperbaiki mutu air supaya tidak memicu perkembangan virus di tambak.

\section{UCAPAN TERIMA KASIH}

Penulis mengucapkan terima kasih kepada Drh. Lies Parede M.Sc dan Risa Indriani S.Si. (staf peneliti Virologi Balitvet, Bogor) dan Ir. Muharijadi A.M., M.Sc. (Ketua Kelompok Peneliti Patologi, Balitkanta) atas bimbingannya selama penelitian dan penulisan laporan ini berlangsung. Terima kasih pula kepada para teknisi Laboratorium Patologi Balitkanta (Nurbaya, Nurjanna, Indo Lette dan Nur Hidayah) dan teknisi laboratorium Virologi Balitvet, khususnya Nana Suryana dan Kusmaedi yang dengan tekun membantu para penulis sehingga penelitian ini dapat terselenggara dengan sukses.

\section{DAFTAR PUSTAKA}

Anonimous. 1996. Aquaculture for food sufficiency and industry stability. 1996. Highlights. SEAFIDE( Aquaculture Department Tigbauan, Iloilo 5021. Philipines. 4.
Burgess,G.W. 1988. ELISA technology in diagnosis and research. Graduate School of Tropical Veterinary Science, James Cook University of North Queesland Townsville, Australia. $341 \mathrm{pp}$.

Chen, S.N. and G.H. Kou. 1989. Infection of cultured cells from lymphoid organ of Penaeus monodon Fabricius by monodon-type baculo virus (MB). J. Fish Diseases 12:73-76.

Lewis, D. 1986. An Enzyme-Linked Immunosorbent Assay (ELISA) for detecting Penaeid Baculo Virus. J. Fish Diseases, Vol. 9:519-522.

Langdon, J.S. 1989. Experimental transmission and pathogenicity of Epizootic Haematopoitic Necrosis Virus (EHNV), in red fin perch, Perch a fluvialitis $\mathrm{L}$ and 11 other teleost. Journal of Fish Diseases. Vol. 12:295-310.

Lightner, D.V. 1996. A handbook of shrimp pathology and diagnostic procedures for diseases of cultured penaeid shrimp. The World Aquaculture Society. Baton Rouge, Louisiana, 70803 USA.

Madeali, M.I., M. Atmomarsono, A. Tompo, Muliani, Burhanuddin, M. Mangampa, M. Tjaronge, Suharyanto, Utojo, S.Tahe, Gunarto, Nurjanna, Nurbaya, R. Yulianingsih, Sutrisyani. 1997. Peningkatan kesehatan lingkungan tambak udang. Laporan Teknis Hasil Penelitian Balai Penelitian Perikanan Pantai, Maros. 31 halaman.

Mangunwiryo, H. 1990. Pengenalan penyakit virus pada ikan dan udang serta kemungkinan pengendaliannya. Prosiding Seminar Nasional II Penyakit Ikan dan Udang. Bogor, 16-18 Januari 1990. Balitkanwar-SEAMEO BIOTROP dan IDRC-Canada.

Nadala, E.C.B., L. M. Tapay, S. Cao, P. C. Loh. 1997. Detection of yellowhead and Chinese baculovirus in penaeid shrimp by the Western blot technique. Departement of Microbiology, University of HawaiiManoa. 207 pp.

Parede, L. 1997. Kursus singkat "Antibodi Monoklonal". Jurusan Farmasi ITB Bandung 14 Juli 1997. 11 hal.

Puslitbang Perikanan. 1994. Distribusi geografis organisme patogen pada ikan. Laporan IIasil Penelitian Proyek ARM tahun 1993-1994. 12 hal.

Sano, T., T.Nishimura, H.Fukuda and T. Hayashida. 1986. Baculoviral infectivity trial on Kuruma Shrimp larvae, Penaeus japonicus of different age. In Fish and Shellfish Pathology. (A.E.Ellia,Ed.). Academic Press, London: 397-403.

Zola. H. 1987. Monoclonal antibodies: A manual of techniques. Departement of Clinical Immunology Flinders Medical Centre and Flinders University of South Australia, Redford Park, Australia. CRC Press, Inc. Boca Raton, Florida. 214 pp. 